\title{
Em busca das razões para o voto: o uso que o eleitor faz da propaganda política Luciana Fernandes Veiga*
}

\begin{abstract}
RESUMO
A expansão do marketing politico televisivo e a sua crescente influência no processo eleitoral têm despertado a atenção dos cientistas políticos. Diante do processo de personalização da politica decorrente da exposição direta do candidato ao eleitor através da televisão, o meio acadêmico aponta para a necessidade de revisão dos modelos explicativos de decisão do voto existentes. Este trabalho vai ao encontro de tal demanda, o seu objetivo é examinar como os eleitores processam as mensagens politicas divulgadas pelo Horário Eleitoral e como as utilizam na decisão do voto.
\end{abstract}

*Luciana Veiga é doutoranda em Ciência Politica - IUPERJ e pesquisadora do Doxa -Laboratório de Comunicação Politica e Opiniảo Pública, IUPERJ. 
O trabalho está baseado em uma investigação empírica realizada na ocasião da disputa presidencial de 1998, quando buscamos analisar o impacto persuasivo do Horário Eleitoral sobre o homem comum, sendo este definido a partir de critérios de baixa escolaridade, baixa renda e baixo interesse pela política. $O$ trabalho utilizou-se de pesquisas qualitativas, com entrevistas em profundidade e grupos de discussão, realizadas durante todo o período da disputa.

Os resultados obtidos apontaram que o eleitor raciocina sobre os candidatos, os programas de governo e os temas relevantes da campanha ao decidir o seu voto. O Horário Eleitoral é visto como fonte importante de informação na medida em que aumenta a exposição dos políticos na mídia e oferece informações mais assimiláveis: O eleitor seleciona e processa as mensagens veiculadas pelas propagandas a partir de seu estoque de conhecimentos e de seus valores. O Horário Eleitoral oferece argumentos para o eleitor defender sua atitude sobre o voto nas conversas do dia-a-dia, onde de acordo com os dados empíricos, as opiniões se cristalizam.

1. Racionalidade do Voto e Ideologia Política: as 184 conseqüências da escassez de conhecimento e da alienação
politica para a formação da preferência.

Partimos do princípio que para identificar o efeito da propaganda é preciso entender o que o eleitor "faz" com a propaganda. Ao analisarmos o que o eleitor faz com as mensagens das campanhas podemos identificar um eleitor que raciocina ao decidir o voto.

Desta maneira, o eleitor analisado lembra o eleitor descrito por Popkin (1991), pessoas que raciocinam sobre os candidatos, suas propostas e os temas mais relevantes na campanha. Os eleitores comuns podem ser classificados enquanto racionais, no sentido desenvolvido por Downs(1957), para quem o eleitor ao decidir o seu voto, age a partir de cálculos de interesse e utilidade pessoal, a fim de maximizar ganhos. O eleitor imagina como cada candidato governaria uma vez eleito e identifica que ganhos teria em cada uma daquelas possíveis gestões. Então decide pela opção que acredita lhe render maior ganho.

Contudo, esta avaliação dos elementos da disputa é realizada a partir de conhecimentos e informações fragmentados. Os depoimentos apontam para a pouca importância dada ao assunto política no cotidiano das pessoas comuns. 
Eu não tenh to tempo para ficar falando sobre polínica portue o serviço me preocupa mais e também ficar acompanhando política direto por que? Se na hora que eles ganham eles esquecem isso undo que estão ai prometendo. (grupo realizado em 08/09)

O cotidiano das pessoas possui uma ordem. A rotina do homem comum consiste em acordar cedo, sair para o trabalho, voltar para casa e descansar enquanto fica com a família. O dia-a-dia da mulher comum que trabalha fora pode ser descrito pela já conhecida dupla jornada, isso é, ao chegar em casa clas devem cuidar dos fillos. do jantar, da limpeza da casa e da lavação de roupa. As donas de casa cuidam dos filhos e da casa, prioritariamente. Quando dispõem de tempo, se dedicam aos pequenos serviços remunerados. Assim cada uma destas pessoas segue a sua rotina sem gastar muito tempo e preocupação com qualquer assunto que extrapole o imprescindivel para a continuação deste cotidiano. Ou seja. todo o pensamento e toda ação se manifestam apenas $\mathrm{em}$ conseqüência de uma demanda do dia-idia. Heller (1970) classificou como economicismo do cotidiano tal atitude. Os homens comuns ao perceberem-se alijados do processo decisório da política pública, não vêem utilidade em inserir a política na pauta dos assuntos do seu cotidiano.

O baixo conhecimento sobre os assuntos da política, quando não impossibilita a recepção de informações sobre o tema, torna a mesma muito custosa. Para uma notícia despertar a atenção do indivíduo é preciso que encontre determinados fatores no telespectador. aponta Gade (1998). Percebemos um enunciado se estiver dentro do nosso limiar de percepção. Os participantes corroboram com Gade ao justificarem a sua falta de atenção ao noticiário político. Eles acreditam ser "muito difícil de entender o que o repórter e os políticos falam". Ou seja, a ausência de certas contribuições cognitivas impede que os telespectadores/homens comuns encontrem o que Bransford (1974) chama de click de comprecnsão.

Diante do quadro, a pergunta que se coloca é como o eleitor que possui escassos recursos cognitivos e que reparte da idéia de alienação política decide o voto? De fato, a alienação política aparece como um grande obstáculo para a mobilização dos eleitores. Na medida em que não reconhecem os políticos como representantes de scus interesses, os eleitores demonstram-se desiludidos com a prática da política. Contudo, é preciso ressaltar que existe uma margem para o diálogo entre candidato e eleilor que se situa precisamente no 
reconhecimento por parte da maioria das pessoas que não se trata de os políticos não cumprirem nada do que prometem em campanhas, mas sim a percepção que eles cumprem pelo menos um pouco do que prometem.

Esta percepção de que "pelo menos um pouco eles fazem" motiva o eleitor a obter informações. O eleitor passa então a adotar o comportamento maximizante, descrito por Downs (1957), na medida em que se empenha em escolher entre as alternativas aquela que possa vir a produzir os melhores resultados.

A7: Ladrão por ladrão, coloca qualquer um lá.

A 8: Não, também não é assim, não.

A9: Dependendo de quem você vai escolher a coisa pode piorar. $O$ Horário Eleitoral é importante porque você tem que decidir quem você vai colocar lá. (grupo realizado em 18/08)

Neste contexto marcado pela falta de conhecimento da política, a propaganda eleitoral tem a importante função de reduzir o custo da informação, facilitando o acesso do eleitor comum aos temas relevantes para a decisão do voto. Como consequiência, o efeito persuasivo da propaganda eleitoral pode ser medido conforme a capacidade desta em se comunicar positivamente com o eleitor, oferecendo argumentos de fácil entendimento e verossímeis.

O povo, se ele não vê o Horário Eleitoral não tem como conhecer os candidatos porque a maioria das pessoas não tem condições de ler um bom livro que fale realmente o que são os políticos, então o pessoal fica perdido. O povo tinha que ter mais informação sobre os candidatos, porque é só na época de política que ouve falar, o que eles estão fazendo. (grupo realizado em 20/08)

A avaliação sobre o futuro desempenho dos políticos envolvidos na disputa acontece a partir de um limitado conhecimento sobre o mundo da política.De acordo com o modelo de raciocínio do eleitor descrito por Popkin (1991), as pessoas ao decidirem o seu voto utilizam-se de informações fragmentadas e insuficientes para o perfeito entendimento do jogo político e do funcionamento do governo. Tais informações utilizadas para simplificar a decisão sobre o voto têm sua origem em experiências passadas e do dia-a-dia, na mídia e nas campanhas políticas.

O Horário Eleitoral, contudo, apresenta limitações de persuasão na medida em que parte dos eleitores reconhece o mesmo como um canal de informação imparcial, onde os candidatos buscam convencelos sobre o voto. 
Estes eleitores partem do discurso sobre a alienação política para justificarem sua postura. Argumentam que os programas e a propaganda eleitoral não informam os eleitores porque os políticos só usam o Horário Eleitoral para se promover. Descrentes, os eleitores recusam a política de maneira geral e particularmente a propaganda eleitoral. Acreditam que não deveria haver programa obrigatório na televisão, não consideram justo que as pessoas sejam privadas de seus momentos de lazer para ouvir mensagens partidárias. Desconfiados, incertos sobre a veracidade das informações veiculadas pela propaganda política, os eleitores preferem se precaver e responder, quando perguntados a respeito, que o Horário Eleitoral não exerce influência na sua tomada de decisão sobre o voto. No entanto, ao contrapormos com a resposta sobre a influência que o Horário Eleitoral tem na tomada de decisão sobre o voto na sociedade como um todo, as pessoas acreditam que o horário eleitoral exerce muita influência.

Desta forma, parece possível concluir que quando a pergunta deixa de se referir à pessoa do entrevistado, quando a expectativa é que ele responda priorizando a preocupação de construir uma imagem mais positiva de si mesmo, em detrimento da resposta verdadeira, podemos perceber que o efeito do horário eleitoral na tomada de decisão ganha relevância. Ou seja, o entrevistado se apresenta como crítico suficiente para não se deixar convencer por aqueles políticos que aparecem no comercial, no entanto, acreditam que a população dá muita importância àquela propaganda na hora de escolher o candidato.

Parece importante destacar desde já que a propaganda eleitoral pode exercer influência de maneira direta e indireta. Muitos depoimentos levantados mostram que grande parte das mensagens que alcança o eleitor por intermédio do Horário Eleitoral chega até o mesmo de maneira indireta por meio dos líderes de opinião que se encarregam de passar as informações a seus amigos e conhecidos. Assim embora os eleitores não acompanhem diariamente a propaganda eleitoral na televisão, eles podem ter sua postura sobre o voto influenciada pelo Horário do TRE, se esta for um reforço de certas visões próprias já estruturadas pelo cotidiano das pessoas. Estes depoimentos demonstram o efeito, indireto, da persuasão do Horário Eleitoral. Em um contex to em que complexas informações devem ser processadas a partir de escassos conhecimentos, a reprodução, ou mesmo a tradução, de um discurso de campanha por um amigo ou parente pode facilitar o processo persuasivo. 
Em suma, podemos verificar como a falta de conhecimento sobre os assuntos da política aumenta o custo da informação. Identificamos ainda como a alienação política reduz a expectativa de benefícios futuros a partir do voto. Contudo, na busca de potencializar o seu voto, assegurando assim o máximo de ganhos futuros, os eleitores comuns buscam maiores conhecimentos sobre os candidatos e os temas da disputa para tomarem a sua decisão. O Horário Eleitoral tem por objetivo atender a esta demanda de informação. Ele é capaz de mobilizar a população para o pleito na medida em que aumenta a exposição dos políticos na mídia e disponibiliza para o eleitor um discurso mais assimilável.

\section{A Utilidade do Horário Eleitoral}

O início do Horário Eleitoral indica para os homens comuns pesquisados que está na "hora da política". Tal percepção gera uma necessidade nos eleitores. Eles precisam votar e precisam se informar para votar. Reconhecem o Horário Eleitoral como o espaço por excelência para buscar as informações sobre os candidatos e suas propostas, devido a facilidade de acesso à informação. É assim que o Horário Eleitoral mobiliza os eleitores. É possível perceber que neste momento o homem comum passa a ser um consumidor de informações eleitorais. É obvio que tudo isso acontece dentro do limite do economicismo do cotidiano.

O efeito do Horário Eleitoral passa a estar vinculado então à satisfação das necessidades experimentada pelo eleitor. Esta afirmativa nos remete à Teoria dos Usos e Gratificações. De acordo, com esta teoria, a mídia só se torna eficaz quando o próprio receptor lhe atribua tal eficácia, baseando-se precisamente na satisfação das necessidades.

A Teoria dos Usos e Gratificações surgiu com o objetivo de obter evidências empíricas sobre os efeitos dos meios de comunicação na audiência (D'Adamo, 2000). Katz (citado em D'Adamo, 2000) propôs mudar a atenção do que os meios fazem com a audiência como a Teoria dos Efeitos se propunha - para avaliar o que a audiência faz com os meios. Assim a Teoria de Usos e Gratificações contempla os membros do público como usuários ativos do conteúdo dos meios. Os membros do público fazem uso da mensagem e esta utilização atua como variável que interfere no efeito.

Katz sintetiza os objetivos da Teoria dos Usos e Gratificações: entender os motivos para o consumo dos meios, explicar como as pessoas utilizam os meios para satisfazer as suas necessidades, 
identificar as funções e as conseqüências das necessidades. Para o autor, a necessidade move o uso.

Sobre as funções psicológicas e sociológicas das comunicações de massa, segundo Katz (citados em Martins, 1996) a mídia satisfaz as seguintes necessidades dos indivíduos: cognitivas, afetivas e estéticas. de integração ao nível de personalidade (segurança, estabilidade emocional, incremento da credibilidade e da posição social), de integração a nível social e necessidade de evasão. Ao analisar o material empírico desta pesquisa, é possível identificar as necessidades dos eleitores participantes e como suas demandas eram ou não supridas pelo Horário Eleitoral.

Os eleitores ao assistirem a propaganda política buscavam conhecer melhor os candidatos e seus programas de governo. A fim de diminuir a incerteza que caracteriza a decisũo eleitoral, as pessoas comuns buscavam informações sobre as propostas de governo dos candidatos para assim criarem um possivel governo do mesmo. uma vez este eleito. Demandavam também informações que oferecessem garantia de que, de fato, as propostas seriam passíveis de realização.

Eu acho que o Horario Eleinoral deveria ter ontro sistema para divisão do tempo. Os candidatos desconhecidos cono o Ciro e o Enéas deverian ter un tempo maior para a gente poder conlecer: (grupo realizado em 1S/OS)

O que mais chamou minha atenģão no Horário Eleitoral de hoje foi o Fernando Henrique falando sobre n que ele fez pela saúde. Eu não conhecia esta parte. En achava que ele não estara nem ligando para a sande. O programa me ajudou a conhecer a parte da sande. troure informação nova. (grupo realizado em 27/0S)

Eu creio que o Horairio Eleitoral influencia, sim. Você presta atenção no que o candidato está falando. Se não houresse tantas criticas e eles apresentassem o plano deles, dava para a gente conhecer mellor: (grapo realizado em 22/09)

Analisando a propaganda, a gente fica en dívida. Lula fala coisas boas, ane vai resolver o desemprego, mas näo fala exatamente como.(grapo realizado em 25/08)

Os políticos podiam falar de coisas mais fáccis. Porque este négócio de estatal. para gente que não tem certo entendimento só faz a gente ficar com medo de ser mandado embora do serviģo. (gripo realizado em 0.5/09

As demandas cognitivas apresentadas pelos eleitores pesquisados estão interligadas àquelas que Katz (citado em D' Aldamo, 2000) chama de demandas de integração ao nível da personalidade. A busca dos eleitores por aquisição de 
conhecimentos e por compreensão do cenário de campanha visa atender uma necessidade de segurança e de estabilidade emocional, através do incremento da credibilidade em relação aos candidatos.

A campanha de Ciro Gomes dedicou-se primordialmente à construção da imagem do político em detrimento da apresentação de seu programa de governo. O eleitor percebeu tal estratégia. Ciro Gomes chegou a despertar uma imagem positiva, mas porque os eleitores não tomaram conhecimento de suas propostas, ficaram sem ter como criar um mundo futuro com Ciro presidente. Assim, parte das necessidades dos eleitores não foi atendida.

O Ciro tem deixado a desejar até certo ponto. Ele é uma pessoa reservada, mas não fala do plano de governo. A gente fica sem saber.(grupo realizado em 08/09).

Por sua vez, Lula deu grande ênfase na construção de um mundo atual muito ruim, mas dedicou pouco tempo em propor um mundo futuro diferente. A escassez desta informação foi sentida pelo eleitor abaixo. $O$ eleitor concordava com o mundo atual descrito por Lula, sentia as consequiências deste mundo em sua vida privada e, por isso, o programa de Lula chamou a sua atenção. No entanto, este programa não foi capaz de despertar credibilidade no eleitor de modo a assegurar a sua estabilidade emocional. Na visão do eleitor/telespectador, o candidato não apresentava o seu programa de governo e não se comprometia com a realização de suas promessas.

O PT é o partido da desgraça. Ele só mostra os erros e não mostra as soluções. Lula falou o tempo todo no programa dele que o Fernando Henrique não investiu na educação, não investiu nisso e naquilo. Eu até concordo, acho que ele vem errando há muito tempo. Mas se ele mostrasse: "o meu plano é fazer isso e aquilo e se eu não cumprir podem me tirar do governo". Ia ser diferente. A minha maior ansiedade, por exemplo, é ver meu filho educado. (grupo realizado em 17/09)

A demanda cognitiva associada à demanda de integração ao nível de personalidade ganha relevância entre os homens comuns na hora da decisão do voto. Sem possuírem muito conhecimento sobre o mundo da política buscam qualquer informação que venha minimizar o seu estado de insegurança sobre o voto. Neste ponto as características pessoais ganham relevância para o eleitor. Trata-se de um claro resultado da nova relação política e mídia, que expõe o candidato ao eleitor de maneira direta.

A5 - Eu ia votar no Lula, mas depois que eu assisti o programa do Fernando Henrique, eu achei que ele se mostrou tão seguro, tão firme, que se eu fosse votar hoje eu votaria nele. 
Debatedora - O programa é que fé rocê mudar de opinião?

A5 - É, por causa do programa. Porque a gente quer segurança ele passa isso. Se en fosse votar hoje, wraria nele (grapo realizado em /SI 08).

Eu acho que Fernando Henrique é o melhor para garantir a moeda forte por causa da seriedade dele e também porque ele tem passe live para qualquer reunião em todo o mundo. Qualquor coisa que aconteģa no mundo. ele é convidado. (gripo realizado em 27/0S)

O comportamento dos eleitores acima corrobora para o que Sears (FREEDMAN et alli, 1973) aponta como uma tendência universal. As pessoas formam extensas impressões dos outros com base em informações muito limitadas. Os eleitores comuns se comportaram desta maneira, ao examinarem o rosto, as feições. as roupas, a qualidade e o timbre de voz dos candidatos, de modo a elaborar que espécies de Presidente poderiam vir a ser. Sears aponta ainda que embora os indivíduos não se mostrem muito confiantes nas opiniões que formam, ainda assim, cles estão dispostos a avaliar a inteligência. a idade, a honestidade $c$ a afetividade. Tal disposição apresentada pelos eleitores buscava minimizar a ansiedade sobre a decisão do voto. emotivas.

Os eleitores também demandam experiências estéticas e

Para a gente que não analisa o bastamte, ama muisica bem tocada. um lugar bonito, una imagem bem nsada. .em am reflero a pessoa diz: é nele que en rou votar (grupo realizado em 27/(OS)

Entre as demandas aprescntadas pela Teoria dos Usos e Gratificações, a única demanda que não conseguimos identificar nos eleitores participantes refere-se à necessidade de evasões e abrandamento das tensões e conflitos. Ao contrário. o período cleitoral parece instigar o conflito, principalmente. o conflito social. Esta questão foi acentuada devido à participação de um candidato do perfil de Lula. que enfatiza a imagem de homem do povo.

Você pode prestar a atenção que na parte dos artistas aparece o Antônio Ermírio de Moraes, que é um dos homens mais ricos do país. Por que cle está apoiando o Fernando IIenrique? Porque quem lem murito, sempre está querendo ganhar mais. Agora a massa fica apagada. Eu son aposentado. näo tenho casa própria, pago aluguel. o SUS esta do jeito que está. Vai rocê precisar da ajuda de am político? "Fala que en não estou, esse cara é chato". (Grupo realizado em 17/09)

Por fim, os eleitores demandam que a propaganda política ofereça argumentos que reforcem os contatos interpessoais com a família e com 
os amigos. A política no período eleitoral faz parte dos assuntos que são debatidos nos aniversários, nos bares, no ponto de ônibus, em uma conversa rápida com o vizinho ou com amigo de trabalho. Particularmente, os líderes de opinião demandam maiores conhecimentos para que possam exercer maior influência em seus grupos.

Até duas semanas eu estava sem saber em quem votar, não estava nem me preocupando com isso. Eu tenho um amigo que é muito ligado em política. Então eu perguntei ao Marlon em quem ele ia votar para presidente. Aí ele respondeu: É no Lula, é lógico. E ai ele comę̧ou a me falar um monte de coisas. Mesmo tendo certeza que o Lula não vai ganhar; eu vou votar nele. (grupo realizado em 15/09)

Sintetizando, o eleitor comum a partir de escassos recursos cognitivos e da alienação política se demonstra pouco motivado para o pleito. Contudo, o processo decisório sobre o voto avança motivado pela expectativa do eleitor de maximizar as suas oportunidades. O eleitor, mesmo descrente, busca "errar menos", votando em alguém que "faça pelo menos um pouco do que prometeu". Para identificar entre os candidatos qual melhor procederá, caso eleito, o homem comum busca informações na mídia e na conversa do dia-a-dia. Nesta situação, o Horário Eleitoral ocupa - local por excelência da discussão sobre a disputa. Os eleitores assistem o Horário Eleitoral para se informar sobre os candidatos e os seus programas de governo e tentam assim atender a uma demanda cognitiva. Ao obterem maiores informações, as pessoas comuns ficam mais seguras sobre a decisão e suprem assim a uma demanda ao nível de personalidade. Os eleitores ainda buscam, na propaganda política, argumentos que possam ser utilizados nas conversas do cotidiano. Atendem assim a uma demanda de interação social. Com esta predisposição, o eleitor comum se expõe à propaganda eleitoral.

\section{3 . Como o Homem Comum Seleciona e Processa as Mensagens Veiculadas pelo Horário Eleitoral}

A propaganda política tem um caráter persuasivo, ela busca formar atitudes, visando influenciar a intenção de voto do indivíduo. No início do século $\mathrm{XX}$, duas vertentes predominaram na elaboração dos estudos voltados para determinar os resultados da ação de comunicação. As teorias desenvolvidas por Lazarsfeld (1954) sobre a recepção seletiva e a conseqüente teoria da comunicação em dois níveis em muito vão ajudar a explicar o processo de processamento da propaganda eleitoral e como os homens comuns elaboraram sua decisão sobre o voto. 
Nos mesmos anos 40 e 50 . Hovland organizou programas de pesquisas sobre a mudança de atitude a partir da persuasão dos meios de comunicação de massa, a fim de fornecer dados úteis para aumentar a eficácia da mensagem, ou seja, para assegurar os efeitos pretendidos pelo emissor:

A maior contribuição de Hovland para este trabalho se refere à teoria de assimilação e contraste. Trata-se de uma tentativa de adaptar a sua teoria da mudança de atitude para o contexto da mídia. De acordo com o psicólogo social, as diversas mensagens são assimiladas quando não as julgamos muito diferentes de nossas idéias sobre um referido assunto e, contrariamente, as mensagens que apresentam posições muito diversas são rejeitadas como se fossem mais divergentes das nossas idéias do que são na realidade.

Wolf (citado em Martins, 1996) busca resumir as idéias de Hovland. De acordo com o mesmo, a recepção e o processamento da mensagem acontecem em situações específicas. Acontecem quando emissor e destinatário repartem da mesma opinião. Acontece quando a diferença entre as opiniões do indivíduo e as opiniões do emissor não são excessivas. Acontece ainda quando oenvolvimento a adesão do destinatário a o assunto da mensagem são pequenos e fracos. Hovland delimita assim o campo de aceitação. Já no campo da recusa, enquanto oposição, a mensagem é recebida como propagandista e inaceitável, provocando um efeito de contraste que faz com que a diferença entre as opiniões próprias e as opiniões da mensagem pareça ainda maior do que de fato é.

Ao buscar explicar como o eleitor comum selecionava e processava as mensagens políticas é preciso abordar a Teoria da Recepção Seletiva. A coerência das mensagens veiculadas com os valores e atitudes dos eleitores fazia com que a propaganda despertasse mais a sua atenção. Foi possivel perceber que aqueles eleitores que possuíam uma postura sobre o voto tendiam a prestar mais atenção e assimilar melhor a propaganda de seu candidato que de qualquer outro. Desta forma, os valores e atitudes serviam como um bloqueio para o diálogo com os demais candidatos, dificultando a comunicação.

A partir da análise dos questionários aplicados junto aos participantes na ocasião da realização dos grupos, é possivel verificar que nas 20 reuniões realizadas, $29 \%$ dos participantes apresentavam inclinação de voto para Fernando Henrique, $35 \%$ apresentavam intenção de voto em Lula e $23 \%$ diziam-se indecisos sobre a escolha do 
candidato. Ao acompanhar o movimento das intenções de voto, fica fácil perceber que aqueles participantes que possuíam uma prévia inclinação partidária apresentavam maior resistência em mudar de atitude em relação ao voto. Enquanto isso os eleitores indecisos demonstraram-se muito receptíveis a tais mudanças.(Figura 1)

Os resultados corroboram para a Teoria da Recepção Seletiva de Lazarsfeld e ainda para a teoria de Hovland. Pelo quadro é possível verificar que os campos de aceitação dos discursos de Fernando Henrique e de Lula estavam restritos aos eleitores partidários de cada candidato e aos eleitores indecisos. A aceitação dos discursos de campanha pelos eleitores/participantes partidários pode ser percebida na medida em que houve apenas um pequeno número de mudanças de intenção de voto. $\mathrm{O}$ que indica que as opiniões partidárias prévias foram em geral cristalizadas pela propaganda eleitoral. A aceitação do discurso de campanha pelos eleitores indecisos pode ser verificada na medida em que diante à exposição dos argumentos de campanha, os mesmos elaboraram uma atitude a respeito do voto. Neste espaço, as mensagens veiculadas pelos candidatos foram avaliadas pelos eleitores comuns como objetivas e aceitáveis. O campo da recusa se referia à campanha do adversário, cuja mensagem era recebida como propagandista e inaceitável.

Figura 1 - O efeito do processo de persuasão Saldo acumulado de ganhos e perdas após cada programa

$\begin{array}{lllll}\text { Intenção de voto } & \text { Entrada } & \text { Ganhou } & \text { perdeu } & \text { Saiu } \\ \text { Fernando Henrique } & 28,6 \% & 9,3 \% & 4,4 \% & 33,5 \% \\ \text { Lula } & 34,6 \% & 8.8 \% & 1,1 \% & 42,3 \% \\ \text { Ciro Gomes } & 5,5 \% & 4,4 \% & 1,1 \% & 8,8 \% \\ \text { Enéas } & 3,3 \% & 2,2 \% & - & 5,5 \% \\ \text { Indeciso } & 23 \% & 0,5 \% & 18 \% & 5,5 \%\end{array}$

A dificuldade em levar a mensagem até alguém que discorde dela pode ser justificada por fatores de ordem social. O indivíduo sofre pressões para que adote posturas afinadas com suas atitudes anteriores e aceitas pelos grupos, fazendo com que tenda a recusar argumentos adversários ou a reprova-los.

Tal postura dos eleitores pode ser explicada por Sears (1967) para quem um indivíduo diante de uma comunicação discrepante busca provas que apóiem a sua posição. A propaganda adversária só gera tensão quando o eleitor sente que os argumentos da parte contrária são sólidos e irrefutáveis. Desde que possa refuta-los, a tensão será 
reduzida. Portanto, a refutação dos argumentos do candidato adversário, ou do próprio candidato, constitui um meio de resolver a discrepância entre as duas posições.

Hovland (citado em FREEDMAN et alli, 1973) aponta como o indivíduo se desvencilha dos argumentos que constituem a comunicação discrepante através do que denomina modos alternativos de resolıção. A rejeição de argumentos, muitas vezes sem nenhuma razão evidente, é o mais comum de todos os modos de resolução.

Ali nenhum político me convenceu. O que eles falam ali não convence, são só promessas. (grupo realizado em 10/09)

Alguém que se encontre diante de uma comunicação discrepante poderá reduzir a tensão ao decidir que a fonte da comunicação é inidônea ou negativa, por este ou aquele motivo. A estratégia de descredenciar a fonte conduz ao equilíbrio das atitudes na medida em que nada existe de incoerente no fato de se discordar de uma fonte negativa.

O Fernando Henrique falou ali na propaganda que quatro anos é pouco. Ele quer passar de- trinta anos? Para quêe? Para viajar? Porque qual foi o dia em que ao invés de estar viajando para o exterior; ele estivesse subindo o morro de uma favela? Qual foi o dia em que ele chegon para ver se faltava remédio ou médico em um posto de saúde? Vocês jả viram isso alguma vez na televisão? Eu munca vi. Tem que dar a chance para o ontro mesmo.(grupo realizado em 17/09)

Atacar a fonte de comunicação é um recurso extremamente eficaz porque não só elimina a ameaça representada pelo argumento adverso, mas também tornam menos poderosos os argumentos futuros que um antagonista possa utilizar. Assim, atacar o candidato adversário é um modo eficiente de reduzir a tensão produzida por uma comunicação discrepante.

Contudo, se faz necessário chamar atenção para o efeito boomerang, uma provável consequiência da propaganda negativa. Em seu artigo Voter Responses to Negative Political Ads (1984), Garramone utilizou o conceito de Surlin e Gordon (1977) para definir propaganda negativa como aquela que ataca os candidatos adversários pessoalmente, os temas que eles sustentam ou os seus partidos. Segundo Garramone (1984), o efeito intencionado desta espécie de propaganda eleitoral é criar um sentimento negativo junto ao candidato alvo e um sentimento positivo 
em relação ao candidato emissor. Esse impacto, porém, é determinado pela percepção, por parte do receptor, da veracidade da mensagem. Uma vez detectada a veracidade das informações veiculadas, o comercial tem a aprovação dos indivíduos e gera uma rejeição junto ao público alvo. Por outro lado, um forte ataque a um candidato, se percebido como nãoverdadeiro pela audiência, pode criar uma rejeição maior ao emissor do que em relação ao alvo. Meros ataques apenas despertam repúdio dos eleitores, que estão assistindo o Horário Eleitoral a fim de obterem informações concretas a respeito de candidatos e propostas de governo que venham ajuda-los na decisão do voto. Falar mal é perda de tempo, não traz conhecimento. Criticar aumenta a incerteza do eleitor, causando ainda mais mal estar no mesmo. Desta maneira, um ataque ao adversário para ser eficiente deve ser bem documentado.

Dando seqüência à enumeração dos modos de resolução de discrepâncias, o eleitor pode ainda distorcer e interpretar de maneira desvirtuada a propaganda de modo a reduzir a discrepância entre a posição pessoal e a da comunicação. O seguinte eleitor acredita que a propaganda eleitoral seja um engodo e para justificar sua postura, vai pausadamente desconstruindo os discursos dos diferentes candidatos.

Lula é o perfeito. Ele diz que vai resolver o problema do desemprego, só não fala como. Ao mesmo tempo, diz que vai investir não sei quanto em seguro-desemprego. Se ele vai resolver o problema do emprego, por que investir tanto no seguro desemprego? Só bobo para falar uma coisa desta. (grupo realizado em $25 / 08$ )

Para que o eleitor aceite a mensagem persuasiva das campanhas, o processo deve se inverter. Agora dois fatores parecem determinantes: a confiança na fonte da mensagem e a força do próprio discurso. Se o eleitor não confia minimamente no candidato, não aceitará a comunicação. Do mesmo modo, se a mensagem não é suficientemente forte para convence-lo e nem suficientemente discrepante para atacar a sua posição, não haverá pressão sobre o alvo para que ele mude.

Quando uma comunicação persuasiva apresenta uma posição que é discrepante daquela sustentada pelo alvo, a tendência é a descrença ou a desconfiança da mesma. Esta falta de confiança, geralmente, gravita em torno da fonte de comunicação-ele é um indivíduo desonesto, estúpido, mal informado - mas pode ser produzida também pela própria comunicação - é tão tendenciosa e exagerada que perde toda a sua credibilidade. $\mathrm{Na}$ medida em que a desconfiança é despertada, é improvável que o alvo seja influenciado. Quanto mais idôneas foram a fonte e a mensagem, mais 
provável é que a pessoa aceite o que a comunicação diz e mude de atitude. Desta maneira, um papel importante da propaganda eleitoral é construir e reforçar este caráter positivo no candidato, a fim de defender o político de ataques de adversários e de defender os seus eleitores de conseqüentes desconfianças. Desta forma, faz parte da estratégia de uma campanha assegurar os votos já conquistados, oferecendo bons motivos para os eleitores partidários.

A credibilidade do comunicador é uma variável que possui a maior potencialidade no modelo para mudança de atitude, desenvolvido por Hovland. A credibilidade procede e depende de dois elementos fundamentais: a competência ou experiência atribuída à fonte e a confiabilidade. De acordo com Hovland (citado em FREEDMAN et alli, 1973), quanto maior for o prestígio do comunicador maior será a probabilidade de mudança. Os niveis de especialização e autoridade atribuídos ao comunicador na área de interesse determinam até que ponto este será respeitado pelo público alvo.

A confiabilidade procede da aparência de sinceridade, de desinteresse de resultados e da falta de interesse de persuadir a fonte. A confiabilidade estimula a percepção de que o comunicador é sincero e atua de maneira desinteressada. Se for percebido como alguém que lucra com a posição que advoga ou que assume essa posição por quaisquer outras razões pessoais, será menos persuasivo do que uma pessoa que defenda essa posição por razões inteiramente objetivas.

Um problema que se coloca é como convencer um eleitor de que um político em uma campanha eleitoral é uma pessoa desinteressada. Uma solução eficiente é o político fazer a defesa de uma posição que parece ser contrária aos seus interesses pessoais. A confiabilidade aumenta significativamente quando a fonte é capaz de argumentar contra seus próprios interesses ou sustentar uma posição que é obvio que perderá a popularidade (Walster et alli. 1966).

Q7: Como você não confia nele? Ele é um cara sério, fala tudo o que tem que falar: Ele não chamon o aposentado de vagabundo na lata?

Para que o eleitor mude a sua atitude é preciso ainda que a mensagem seja nitidamente ouvida e claramente compreendida. Caso a comunicação apresente argumentos fracos e de maneira vacilante, o eleitor pode refutar, distorcer ou ignorar os mesmos.

Nesta parte procuramos identificar os mecanismos utilizados pelo eleitor comum para selecionar e processar as mensagens eleitorais. 
Podemos verificar que ao se exporem à propaganda política, eles o fizeram de maneira seletiva aceitando aquelas mensagens que se aproximavam de suas ideologias e rejeitando as mensagens que não eram afins com suas posturas anteriores. $\mathrm{O}$ eleitor rejeitou as mensagens veiculadas pela propaganda eleitoral: negando-as, descredenciando a sua fonte e atacando o valor da própria propaganda. Para aceitar as mensagens, o eleitor comum considerou as propostas e avaliou os candidatos pessoalmente. As propostas concretas e passiveis de realização se demonstraram mais persuasivas. Da mesma forma, o candidato que demonstrava maior autoridade nos assuntos públicos despertava mais confiança no eleitorado. Contudo, podemos verificar que o processo de cristalização da opinião demandava a validação dos grupos.

4. Processo de Decisão Uniforme e Formação de Preferencias Diversas: a importancia da hierarquização individual dos valores.

Esta última parte do trabalho visa analisar o que podemos chamar de última etapa do processo decisório sobre o voto. Nosso objetivo é mostrar como a hierarquização dos elementos da ideologia política, realizada pelo eleitor, influencia o processamento das mensagens das campanhas na hora da escolha do candidato. Parece importante ressaltar que embora os homens comuns analisados tenham formulado diferentes preferências eleitorais a partir da prioridade que deram aos diferentes elementos ideológicos, eles realizaram um processo de decisão uniforme.

A seguir, veremos como os participantes hierarquizaram suas crenças, a partir dos discursos de campanha, ao elaborarem a sua preferência. Serão estudados os dois principais candidatos da disputa.

\section{1) O Processo de Decisão do Voto em Fernando Henrique}

O participante eleitor de Fernando Henrique ao decidir o seu voto comportou-se de modo semelhante àquele participante eleitor de Lula. Como já foi apresentado acima, estávamos trabalhando com homens e mulheres que no momento eleitoral buscavam maiores informações para decidirem o seu voto. Usavam informações acessíveis, de modo a diminuir o custo do voto. Paralelamente, buscavam entre as alternativas presentes àquela que maior retorno poderia trazer em termos de implementação de políticas públicas. Em meio a tanta insegurança, os eleitores lançaram mão do conhecimento que possuíam 
do passado dos candidatos e de suas características pessoais. Procuravam garantias de realizações de promessas no futuro. Todo este processo de avaliação estava vinculado ao seu sistema de crenças.

A análise do material empírico indica que os eleitores participantes usaram muito mais o passado para orientar suas escolhas do que as propostas relativas ao futuro. Afinal. o passado já fora dado e estava disponível para avaliação.

Esse problema de prometer muito é de todos os candidatos. $O$

Fernando Henrique está á, e se o poro estiver satisfeito, ele vai continuar: (grupo realizado em 25/08).

A participante acima aponta em sua primeira frase para a crença repartida pelo homem comum que todo político promete no período eleitoral e passado este momento, o político esquece o seu compromisso com o povo. Por isso, muita promessa. por si só, não é garantia para um bom futuro governo. Ela busca então a garantia no conhecimento que possui de Fernando Henrique.

Os participantes que votaram em Fernando Henrique se apegavam no ganho mínimo que obtiveram e projetavam outro ganho mínimo com base no passado. Em sua campanha Fernando Henrique divulgava um mundo atual bom, marcado pelo sucesso da estabilidade econômica. Um grupo relevante dos participantes eleitores de Fernando Henrique adotava este discurso para justificar o seu voto.

O gue eut tenho hoje ell comprei com este plano. Por isso, ell voto nele. Se ele conseguiu isso até agora, depois ele pode conseguir muito mais. Mas se outro entrar vai mudar tudo. (grupo realizado cm 29/08)

Ao adotar tal postura, o participante acima parecia persuadido pela retórica da ameaça adotada pela campanha de Fernando Henrique. Tal retórica pode ser ilustrada pelo spot que fazia o telespectador se recordar da época em que a comida, a gasolina e o aluguel subiam freneticamente. Tal estratégia discursiva baseada no temor ganhou relevância diante do cenário da crise internacional. A estratégia obteve sucesso nos grupos pesquisados, na medida em que cram formados por homens comuns, classificados por Lane(1962) como homens pouco contestadores e muito medrosos.

Se ele (Fernando Henrique) não segurar, se ele não estabilizar a moeda, se ele deixar a crise chegar; ai é que vai bagunçar tudo. Vai desvalorizar o Real, vai desvalorizar o salário do empregado, o dólar vai subir: Então ele tem que preocupar é com a estabilidade da moeda. Já pensou se ele deixar cair o Real, o dólar subir; disparar, como é que nós ramos 
ficar? A desvalorização do nosso dinheiro. Nós vamos chegar no supermercado e 100 reais não vão dar mais para comprar um pacote de arroz. (grupo realizado 15/09)

Nem todos os participantes eleitores de Fernando Henrique avaliavam de maneira tão positiva o primeiro governo do Presidente. Parcela significativa dos participantes que votavam em Fernando Henrique demonstrava críticas ao seu governo. No entanto, reconheciam que alguma coisa ele fizera. A estes eleitores era dirigido o discurso divulgado pela campanha do PSDB de acordo com o qual "ele (FH) não fez tudo, mas fez muito pelo Brasil".

Entre os participantes eleitores de Fernando Henrique estavam aqueles que apresentavam um vínculo muito frágil no momento inicial da disputa, mas que diante da crise internacional e da ameaça à estabilidade da moeda aderiram convictamente a Fernando Henrique. Estes participantes temiam que diante de um cenário de crise internacional, a economia brasileira fosse abalada, sacrificando o seu dia-a-dia.

Para este grupo composto por pessoas apenas relativamente satisfeitas com o governo Fernando Henrique, o motivo do voto na reeleição do Presidente esteve mais vinculado às suas características pessoais que na avaliação de seu primeiro governo. Para os mesmos, Fernando Henrique 200 superava os seus adversários em capacidade e preparo para enfrentar a crise internacional. Assim tais eleitores aceitavam a retórica principal da campanha da reeleição de que somente o mesmo presidente seria capaz de enfrentar ataques especulativos contra o Real e manter a estabilidade. Mesmo conscientes das dificuldades que estavam vivendo e das que poderiam enfrentar no futuro próximo, justificavam a sua intenção de voto em Fernando Henrique reproduzindo o discurso de sua campanha.

Cabe ressaltar que o Jornal Nacional e assim como a contrapropaganda a Fernando Henrique enfatizava o cenário de crise econômica. O eleitor, por sua vez, assumia a percepção de que o Brasil estava inserido em um contexto de interdependência entre as nações, no qual conflitos financeiros no sistema internacional tinham profundo impacto nas escolhas das políticas domésticas. $O$ participante anteriormente citado foi capaz de imaginar as consequiências da queda das bolsas no preço do arroz nas prateleiras do supermercado. Ao prever como a não superação do Governo diante da crise afetaria o seu cotidiano, o eleitor ficou apavorado.

Da mesma maneira como procedeu aquele eleitor satisfeito com o Plano Real, este eleitor comum apenas relativamente satisfeito, 
mas temeroso em relação ao quadro futuro, empenhou-se em criar um mundo futuro a partir da eleição de cada um dos presidenciáveis e concluiu que quem melhor poderia assegurar a estabilização da moeda era o candidato que mais the parecia experiente c competente.

Os participantes que assim se comportaram têm suas atitudes explicadas pela fenomenologia de Schutz (1974). segundo a qual o homem comum procura enquadrar sempre os fenômenos do mundo ao seu universo de experiências rotinizadas. Para concretizar a crise, o participante mapeou suas consequências até o preço do arroz. E expressou que o Presidente precisava segurar a crise. Os participantes demandavam do Presidente um melhor conhecimento a respeito do assunto, que lhes escapava. e a melhor solução do mesmo para o povo. Trata-se do que Schutz chama de recorrer ao especialista. Em entrevistas em profundidade realizadas neste trabalho. os participantes quando perguntados sobre o que seria melhor para administrar o país. o povo ou os políticos, respondiam que acreditavam que o povo conheceria melhor os problemas, mas que o político saberia gerenciar melhor os problemas já que são especialistas nos assuntos públicos. Em última instância, a competência oferecia maior segurança para o homem comum.

A partir da análise dos questionários aplicados junto aos participantes na ocasião da realização dos grupos, é possível verificar a centralidade do argumento da competência de Fernando Henrique na decisão do voto. Acreditavam ser Fernando Henrique o candidato mais preparado para superar dificuldades. $48 \%$ dos participantes. enquanto $37 \%$ diziam ser Lula.

Ao enfatizarem o preparo remetiam a um segundo valor. o estudo. Para superar a pobreza, o preconceito e transitar em qualquer ambiente é preciso ter estudo. O homem comum sente as conseqüências desta regra desde a infância e acaba assimilando e adotando a mesma na avaliação de terceiros.

Uma segunda característica pessoal do presidente que ganhou relevância naquele momento eleitoral foi a suposta seriedade do mesmo.

O candidato Presidente enfrentou grandes desafios naquele pleito. Em plena campanha, devido à crise internacional è à solução adotada pela política econômica governista. Femando Henrique fez subir a taxa dos juros a patamares inconcebiveis para a cconomia que produz $\mathrm{c}$ gera emprego. No entanto, a atitude ao contrario de the causar um maior desgaste, elevou os índices de intenção de voto. A estratégia discursiva 
adotada pelo candidato naquele momento foi muito eficaz em termos persuasivos. Fernando Henrique dizia que os juros altos naquele momento deveriam ser visto como um remédio amargo, que embora ruim, era necessário. Em seus depoimentos dizia que ele não estava preocupado com as consequiências eleitorais de suas medidas econômicas, ele tinha um compromisso com o Brasil, com a estabilidade do Real.

Como Hovland apresenta em seu modelo, nada mais eficiente em termos discursivos que destruir o adversário (e Fernando Henrique o fazia singelamente) e construir uma imagem de altruísta. O Presidente dizia que poderia sair desgastado daquele momento de crise, mas era preciso poupar o Brasil. Fernando Henrique conseguiu então despertar a credibilidade do eleitorado com o discurso de homem competente e confiável. As características pessoais tiveram relevância no pleito na medida em que serviram para ajudar o homem comum na construção de futuro governo Fernando Henrique em contraposição a um futuro governo Lula.

Por fim, uma parcela dos eleitores votou em Fernando Henrique porque não queria votar em Lula. Para parte dos eleitores, Lula é um candidato despreparado e baderneiro. $\mathrm{O}$ mundo futuro com Lula seria o da desordem com muita greve. Temiam ainda um governo marcado pela dificuldade de diálogo com os demais partidos, que geraria o impasse político. Tal temor em um futuro governo Lula era justificado pela percepção de que o homem comum possui da dificuldade de diálogo e conseqüentemente de consenso entre o PT e os partidos situacionistas.

$\mathrm{O}$ homem comum percebe que a política trata da escassez de recursos, o que resulta em conflitos distributivos e que para resolvê-los é preciso conversar, fazer acordos. Sem acordo, qualquer decisão fica paralisada. Desta forma, alguns participantes até gostariam de votar no PT, mas temem a sua fragilidade. Ao contrário, o $\mathrm{PMDB}$ sempre era citado para ilustrar um partido forte.

Não adianta votar no PT e por 450 deputados do PMDB. Adianta? Adianta, nada. O Lula quer fazer um projeto, os deputados não aprovam. Acabou. Ele vai fazer? Não vai fazer. (grupo realizado em 12/09).

Lula vai ganhar e vai fazer o que? O Exército comanda para tirar ele. Tirar o Fernando Henrique? Deixa ele lá mesmo.

- Você vai votar em un tucano?

No tucano, não. Eu vou votar no menos pior. Vou votar no Lula? Eu vou morrer de fome. (grupo realizado em 29/09)

$\mathrm{q} E u$ voto em Fernando Henrique por um motivo, ruim ou bom, a gente não 
tem an governo diferente. Se o pessoal rotar em Lula. o Lula vai ganlar; mas não vai dar conta de fazer nada. Porque ninguém vai apoiar cle em nada. Ele vai ficar de mãos e pés atados. O Senado, o Congresso, ninguém rai apoiar ele, entenden? Só o Fermando Henrique rai ter o apoio de todos.

- Mas por que o Lula não teria apoio e o Fernando Henrique teria?

Porgue o PT é am partido fraco. É am partido da nossa classe. pobre igual à gente. Agora o Fernando Henrique é grande e eles são maioria lá dentro. (grupo realizado em 01/10).

A fragilidade do PT em contraposição à força do PMDB e do PSDB é justificada ainda pela composição de sua bancada. Homens fortes e bem situados socialmente sustentam o PMDB, O PSDB e o PFL. Homens fracos e trabalhadores pouco influentes resultam em um partido de limitado poder de decisão.

Desta forma, ao identificarem Fernando Henrique com um partido forte, os participantes acima decidiam pela reeleição do Presidente por se sentirem mais seguros a respeito do mundo futuro. Vale ressaltar que embora citassem a força do partido do Presidente Fernando Henrique, com frequência, identificavam o mesmo como sendo do PMDB.

Fernando Hemrique foi vitorioso porque persuadiu o eleitorado de que seria o candidato que melhor proveria o mundo futuro. Os participantes que decidiram votar em Fernando Henrique identificavam no mesmo maior garantia de realização através: a) da avaliação do primeiro mandato do político e de seu plano de estabilização da moeda, b) de suas características pessoais de homem capacitado e sério. c) de seu partido forte capaz de garantir a governabilidade. Desta forma, a maior garantia de manutenção da ordem econômica e política em um futuro governo de Fernando Henrique justificavam o volo na recleição do Presidente.

\section{2) O Processo de Decisão do Voto em Lula}

A leitura dos debates aponta que a avaliação do governo Fernando Henrique foi mais central na decisão do voto da oposição que os projetos que estas apresentavam. Os participantes que se manifestaram a favor de Lula olhavam os quatro anos de Fernando Henrique como desastrosos e projetavam a piora do cenário no caso da reeleição. Na negação de Fernando Henrique estava uma das principais fontes de voto em Lula.

Antes de ganhar ele ajudou o pobre e tudo. Quando ele ganhou, ele só misturou com gente rica. Eu acho que com quatro anos o Fernando 
Henrique fez esta limpa toda, com mais quatro anos não vai sobrar mais um pobre. (grupo realizado em 01 de setembro de 1998)

Sem emprego ou com muito medo de perde-lo e com salário baixo, o homem comum que manifestava intenção de voto em Lula assistia cético as promessas de crescimento econômico com estabilidade, apresentadas pelo Presidente candidato. Eram pessoas que haviam se beneficiado com o Real, nos dois primeiros anos do Plano, mas que já naquele período eleitoral sentiam-se excluídos dos benefícios da estabilização da moeda. Para os participantes eleitores de Lula, Fernando Henrique não se preocupava com os problemas das classes mais pobres. Era visto como um presidente distante e sem afinidade com o povo. Desta forma, a idéia de descaso dos governantes em relação ao povo que existe na crença do homem comum, ganhou relevância na disputa. Tal discurso que enfatizava uma postura elitista de Femando Henrique era muito ressaltado pelas campanhas oposicionistas. O participante citado abaixo ao assistir a propaganda em que o candidato governista aparecia junto ao trabalhador fez questão de demonstrar a sua repulsa.

É ridículo ver o Fernando Henrique apertando a mão dos operários de capacetes verdes e amarelos, sendo que ele negou apoio aos trabalhadores quando as montadoras do $A B C$ paulista reduziram a carga horária, reduziram cargos e salários.(grupo realizado em 19 de setembro de 1998)

Os participantes eleitores de Lula reclamavam da ausência do Presidente no país. Acreditavam que ele estava voltado apenas para as grandes questões internacionais e que possuía um grande descaso para com os problemas do dia-a-dia. Insatisfeitos com o governo Fernando Henrique, ao imaginarem um segundo governo do mesmo, estes eleitores decidiam por apostar em Lula.

Eu acho que tinha que dar uma oportunidade a outras pessoas para a gente vê. Eu acho que é um erro ter Fernando Henrique de novo. Ele fez um governo errado e vai fazer outro de novo? (grupo realizado em 18/ 08)

De modo geral, o homem comum ao votar em Lula dizia estar apostando, dando uma chance ao candidato do PT. Como garantia, o candidato oferecia a sua história de vida humilde. Seus eleitores adotavam tal argumento para justificar o voto.

O Fernando Henrique nasceu em um berço de ouro e nunca fez nada. Ele nunca fez nada. Ele vai para o Nordeste, coloca um chapeuzinho, monta no burro, mas ele não sabe o que é aquilo. Agora o outro é trabalhador, tem que apoiar gente assin. (grupo realizado em 22/09) 
Eu fico com o Lula, pelo menos vamos colocar gente nova para ver se vai fazer alguma coisa para nós. Porque nós sempre somos sacrificados, sempre estamos sendo sacrificados (grupo realizado em 19/09).

Os participantes eleitores de Lula vislumbravam a chance de um ganho futuro com a vitória do candidato do PT. Em relação a Fernando Henrique, estavam certos de que nada ganhariam já que na percepção dos mesmos nada ganharam nos quatro anos anteriores. Trocavam a certeza de um futuro ruim com Fernando Henrique pela esperança de um governo melhor de Lula. Descartavam assim as garantias oferecidas por Fernando Henrique. Para os eleitores de Lula, o primeiro governo de Fernando Henrique depunha contra o candidato do PSDB. As características pessoas que oferecia: competência e seriedade; também eram questionadas.

Porque se cultura fosse tirar o Brasil do atoleiro que ele está, nós já tínhamos saído há muito tempo, pois até Presidente membro da Academia Brasileira de Letras nós já tivemos e não adiantou nada. Eu acho que a gente precisa ter é camarada que respeita o povo, que seja extremamente humano.Falta sentimento em Fernando Henrique. Ele gosia é de ir a Suiça. (grupo realizado em 19/09).

Desta forma, atacando a pessoa e o governo de Femando Henrique, os participantes eleitores de Lula iam reafirmando a sua intenção de voto. Estes homens priorizavam a expectativa de maior igualdade e justiça em um futuro governo Lula, faziam tal escolha em detrimento da manutenção da ordem. Em relação às dificuldades de realização de projetos do partido e do candidato. supostamente fracos, eles reconheciam tais limitações, mas estavam dispostos a arriscar. Para estes, valia a pena o risco.

De acordo com os participantes eleitores do candidato do PT, Lula era o político que teria mais condições de resolver os problemas dos pobres, pois os demais candidatos não se interessariam por esta parcela do eleitorado. Lula explorava assim a imagem que o homem comum possui de políticos desinteressados pelas pessoas mais pobres.

De modo geral, os eleitores do candidato do PT adotavam os discursos da campanha oposicionista: avaliavam mal o governo Femando Henrique, concordavam que com a reeleição o Brasil ficaria pior, apostavam na mudança com Lula. As propostas de governo de Lula também eram bem recebidas pelos participantes eleitores do candidato, particularmente, aquelas voltadas para a geração de empregos.

As propostas de incentivo à pequena empresa para a geração de empregos apresentadas e enfatizadas por Lula repercutiam de modo positivo no grupo de participantes. Ao longo da campanha, Lula buscava enfatizar 
sua imagem de defensor dos interesses dos mais pobres agora diante dos efeitos da globalização. Tal estratégia atendia perfeitamente à demanda do homem comum por um Governo atuante na economia em favor da produção, da geração de emprego e de maiores oportunidades para o trabalhador. Tal projeto de governo estava muito afinado com as idéias políticas e econômicas do homem comum. Contrariamente, o projeto de geração de empregos apresentado por Fernando Henrique era questionado. Os participantes eleitores de Lula desconfiavam ser o Presidente muito ligado ao capital internacional e temiam que tal relação viesse a prejudicar a economia interna. As maiores críticas referiam à privatização das estatais para grupos internacionais, o incentivo à importação de produtos e à falta de incentivo à produção nacional através da adoção de altos juros e encargos tributários.

Eu acho Lula ideal porque o Fernando Henrique acabou com o nosso pais. Vendeu tudo o que a gente tinha, a gente não tem mais o que vender. Está transformando o nosso país em um país estrangeiro. (grupo realizado em 01/09)

Hoje, para tudo a gente depende do exterior. Tudo que a gente compra hoje nas lojas é artigo que vem de fora. Esta aí a nossa divida. É como o Lula falou, tem que dar mais chances às pequenas empresas. (grupo realizado em 19/09)

Em suma, o homem comum eleitor de Lula também buscava aquele candidato que poderia lhe garantir melhores benefícios. Este eleitor avaliava de maneira negativa a gestão Fernando Henrique e por isso não vislumbrava um futuro melhor com a sua reeleição. Desta forma, o eleitor preferia apostar na novidade, acreditando que o fato do candidato ter uma origem humilde poderia fazer com que agisse em defesa dos mais pobres, aumentando as suas oportunidades na vida. O eleitor de Lula julgou a sua história (de vida e política) e as características pessoais do candidato. Da origem humilde do candidato, construíram um Presidente futuro voltado pelos pobres.

É preciso chamar a atenção para a fragilidade da garantia apresentada por Lula. Não foram poucos os participantes que gostariam de votar no candidato, dada a sua história de luta, mas que, no entanto, terminaram por votar em Fernando Henrique ou em Ciro Gomes por medo de votar no candidato do PT. 


\section{Conclusão}

Esta pesquisa aponta para um eleitor racional no sentido de que ele busca maximizar os seus ganhos futuros ao elaborar a sua preferência sobre o voto. Ele raciocina sobre os candidatos, os partidos. o cenário político no momento da disputa para tentar "adivinhar" qual daqueles candidatos caso eleito melhor representará os interesses dos eleitores. A fim de suprir a demanda por conhecimentos, de modo a ajudar na tomada de decisão, o eleitor busca o Horário Eleitoral.

O Horário Eleitoral é visto como fonte importante de informação na medida em que aumenta a exposição dos políticos na mídia e oferece informações mais assimiláveis. O eleitor seleciona e processa as mensagens veiculadas pelas propagandas a partir de seu estoque de conhecimentos e de seus valores. Ao obterem maiores informações, as pessoas comuns ficam mais seguras sobre a decisão e suprem assim a uma demanda ao nivel de personalidade. O Horário Eleitoral oferece ainda argumentos para o eleitor defender sua atitude sobre o voto nas conversas do dia-a-dia, onde de acordo com os dados empíricos, as opiniões se cristalizam.

\section{Bibliografia}

BERELSON, Bernard R, LAZARSFELD, Paul F, McPHEE. William. Voting: a study of opinion formation in a presidential campaign. Chicago.TheUniversity of Chicago Press, 1954. BRANSFORD, John D., McCARRELL. A Sketch of a Cognitive Approach to Comprehension: Some thoughts about understanding what - it means to comprehend. In: Cognition and the Symbolic Processes. WEIMER, W.B.E. PALERM D.S., Eds., New York, Lawrence Erlbaum Associates Publishers, 1974.

D'ADAMO, García Beaudoux e FREIDENBERG. Medios de comunicación. efectos políticos y opinión publica. Argentina, Belgrano, 2000.

DOWNS, Anthony: An Economic Theory of Democracy. NY. Harper \& Row Publishers, 1957.

FREEDMAN, Jonathan, CARLSMITH, J. M., SEARS, David. Psicologia Social. São Paulo: Editora Cultrix, 1973.

GADE, Christiane. Psicologia do Consumidor e Propaganda. São Paulo: EPU, 1998.

GARRAMONE, Gina et alli. Effects of Negative Political Advertising on the Political Process. Journal of Broadcasting \& Eletronic Media, vol. $34, n^{\circ} 3,1990$. 
GRABER, Doris Processing the News: How People Take the Information. New York, University Press of American, 1988.

HELLER, Agnes.O Cotidiano e a História. São Paulo, Paz e Terra, 1970.

LANE, Robert E. Political Ideology: Why the american common man believes what he does. New York, The Free Press of Glencoe, 1962. LAZARSFELD, Paul, BERELSON, Bernard, GAUDET, Hazel: The People's Choice, New York, Columbia University Press, 1948.

MARTINS, Beatriz Araújo. Revisitando as teorias da recepção: uma revisão da literatura, dos paradigmas e modelos. Dissertação de mestrado, ECO/UFRJ, 1996.

McGUIRE, William J., "Persuasion" in: Communication, Language and Meaning Psychological Perspectives, MILLER, George, New York, Basic Books Publishers, 1973.

McQUAIL D., WINDHAL, S. Modelos para el estudio de la comunicación colectiva. Pamplona, Eunsa, 1981.

POPKIN, Samuel L._The Reasoning Voter. Chicago, The Chicago University Press, 1991.

SCHUTZ, Alfred: El Problema de la Realidad Social ,Buenos Aires, Amorrortu, 1974.

208 VEIGA, Luciana F.Propaganda Política e Voto: O Estudo do Efeito da Persuasão do Horário Eleitoral - Estado do Rio de Janeiro, em 1994, $2^{\circ}$ turno. Dissertação apresentada ao Programa de Mestrado em Ciência Política/IUPERJ,1996.

VEIGA, Luciana F. Horário Eleitoral, o eleitor e a formação da preferência. Comunicação \& política, volume V, $n^{0} 3$, nova série, setembro-dezembro de 1998.

VEIGA, Luciana F. A Utilização de Métodos Qualitativos na Ciência Política e no Marketing Político. In: Opinião Públical Revista do Cesop, vol. VIII, $\mathrm{n}^{\circ} 1$, maio de 2000 . 